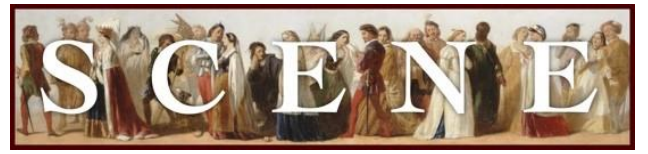

\title{
"A pleasant seat": Macbeth by Public Theater's Mobile Shakespeare Unit
}

\author{
by Gavin Hollis. Written on 2015-04-15. Published in 2017 Issue 1.
}

For the production: Macbeth (2015, Public Theater Mobile Unit, USA). See production details at the end of the review.

“This CASTLE HATH A PLEASANT SEAT; THE AIR / Nimbly AND SWEETLY RECOMMENDS ITSELF / Unto our gentle senses." Highbridge Park Recreation Center, located in Washington Height, New York, has probably never been heralded with such words before, even though the distinctive Romanesque water tower perched adjacent to the center is somewhat castle-like. The beeps and whirrs of Amsterdam Avenue on a Saturday afternoon make the air somewhat less than "sweet." And while the weight room in which the performance took place was filled with a number of seats, it would be a stretch to describe the hastily assembled auditorium consisting of fold-up chairs as recommending to the gentle senses.

Yet despite these limitations, or maybe even because of them, the Public Theater's Mobile Shakespeare Unit's production succeeds in transforming the space of the recreation center into somewhere else: not so much into Macbeth's castle or the haunted battlefields of Scotland, even though these are ably evoked by the performers, but rather, a hybrid space, encompassing the play's geography, the layout of the actual room, and the properties, costumes, and musical instruments that allow for the bridging between audience and actor. Moreover, Highbridge Rec turns out to be a far more welcoming place than Macbeth's castle at Inverness.

The Public's Mobile Shakespeare Unit has been operating for four years, and this production of Macbeth follows Pericles (2014), Much Ado About Nothing (2013), Richard III (2012) and its inaugural production, Measure for Measure (2011). While a recent innovation, the unit has its origins in Public Theater founder Joseph Papp's vision of "Shakespeare belonging to all." But whereas the Public's more storied engagement with the bard, Shakespeare in the Park, invites audiences to come to it (and wait for tickets at some ungodly time of the morning), the mobile unit takes Shakespeare on the road. It produces a number of one-off free performances in recreation centers (in partners with the New York Parks Department), in areas of the city 
without much in the way of theatre culture. The unit also performs at Rikers Island, Lenox Hill Women's Mental Health Shelter, Fort Hamilton, Brooklyn, as well as a number of other detention and correctional facilities, recovery and rehabilitation services, and art and community centers across the five boroughs-all between April 24-May 13 before a short run at the Public's downtown theater (tickets only $\$ 20$ ) between May 17-June 7.

The performance I saw at Highbridge was attended by a diverse audience of approximately fifty (more than the center had anticipated, as some audience members needed to be accommodated with additional seating). And the performance was greeted with a standing ovation, in part because of how the eight-strong cast had thrown themselves into an energetic production (even Rob Dawson, playing Macbeth, doubled for one the murderers), but also for the sheer fact that the downtown Public had brought a free production uptown (a sentiment voiced at the very end by an audience member, and loudly applauded by the audience). It was a wonderful community experience (and as a new resident of Washington Heights-I live on the same block as the Highbridge Rec Center, wonderful for me personally).

For the most part the actors navigate the performance space well, impressively so given they arrive earlier that day and had no opportunity for a run-through. For the production to work the actors need to build on the environment they encounter, and the reactions of the audience, and among the moments that take flight in the production are those where you can see the actors discovering news aspects of character in the interactions between the place and the audience. Given these productions are all one-off, we know as audience members that what we are witnessing is special and unrepeatable-in theory a truism for every play, but perhaps less so for a rigidly blocked Broadway spectacle. In Jennifer Ikeda's first scene as Lady Macbeth, one senses her discovering her own capacity for violent thought in the reading of her husband's letter. That Ikeda doubles as one of the witches is significant-while there are parallels between the sexless witches and the unsexed Lady Macbeth, Ikeda is careful to distinguish them, and finds unexpected sensitivity within Lady Macbeth, a character who can so often devolve into cackling, pantomimic villainy. Keith Eric Chappell is convincing as both the bloody sergeant-a tricky scene-setting speech — and as Banquo, whose playful cynicism gives way to urgency as he begins to sense the depravity to which his friend has sunk. He also makes an appealingly gruesome ghost, haunting Macbeth with little more than mechanistic movements and the blankest of blank stares. Daniel Pearce's Duncan is a more virile presence than we perhaps come to expect (an effect enhanced by the fact that Pearce also plays a gorgeous resophonic guitar in the interstitial moments), in stark contrast to his more morose Macduff. As the former in particular he gives a sense of command to proceedings, which explain all the more how his untimely death creates a rift in Scotland's order. 
However, this is a production that is still finding its feet. It may always be finding its feet given the mobile unit's modus operandi, but the performance at Highbridge was only the second one, and at times it showed. Rob Campbell struggles in particular: having to call for a line is something that can afflict any actor this early in a production's run, and given how disorienting each performance must be for the company, it is a surprise that mistakes don't happen more often. However, Campbell is at this stage still feeling his way through the role. He leans too heavily on Macbeth as "little-boy-lost," which is at times effective, particularly visually so when he adopts Duncan's kingly cloak and crown, only to find that they have been tailored for a much bigger man. His line-reading of "tomorrow and tomorrow and tomorrow," slowed to an almost glacial pace, captures a rare moment of still contemplation in a man not overly given to reflection, and to a production that otherwise moves along a fair old click. However, there is an inconsistency to his performance, and no clear sense of when Macbeth feels that he is "steeped in so far in blood," even though Shakespeare clearly marks the point where he realizes he cannot go back. While Campbell finds some interesting beats in the character, his Macbeth does not yet cohere.

The production also tries to cram in most of Macbeth's characters, which with an eight-strong cast sometimes leads to confusions in the narrative, even if over all this is a well-told tale. I wonder whether the tragedies lend themselves to smaller scale, travelling productions in quite the same that romances do: Pericles, the Mobile Shakespeare Unit's previous production, is, after all, about story-telling, and its large cast almost becomes a virtue, given how individuated many are, and I imagine that the Mobile Unit would be able to stage a Cymbeline or The Winter's Tale very effectively. Macbeth has too many Scots spoiling the broth (Angus, Ross, Siwards Young and Old, Seyton, all fairly un-individuated)—not a problem for a full-scale production but a challenge for a smaller-scale one.

But one scene in particular stood out, even given these limitations. When Nicole Lewis and Teresa Avia Lim entered as Lady Macduff and her son, my sense was that it was not entirely clear to the audience who they were (both actors had already taken a number of roles, including both male and female characters; and Pearce's Macduff somewhat got lost in the shuffle of the multiple Scots). But despite the possibility of confusion here, the scene worked. Lewis and Lim captured the tenderness and intimacy of mother and child, their longing for a missing father and apprehension at his absence. And the murderers (among whom included Pearce himself) were brutal in their assassinations, especially when snapping the son's neck. It was particularly interesting watching the audience: some peered in horror, some looked away. Even if it was not entirely clear who these victims of Macbeth's tyranny were, it was clear that Shakespeare's scene of horror affected the audience members greatly. The intimacy of the stage space, and the 
inability of the audience to escape from the horrors of Macbeth's violence, was brought home at this moment, as a community united in dread at an unspeakable act.

Gavin Hollis is Associate Professor of English at Hunter College, CUNY. His monograph, The Absence of America: The London Stage 1576-1642 is published by Oxford University Press.

\title{
Production Details
}

\section{General}

Title

Year

Theater Company

Theaters

Start Date

End Date

\section{Cast}

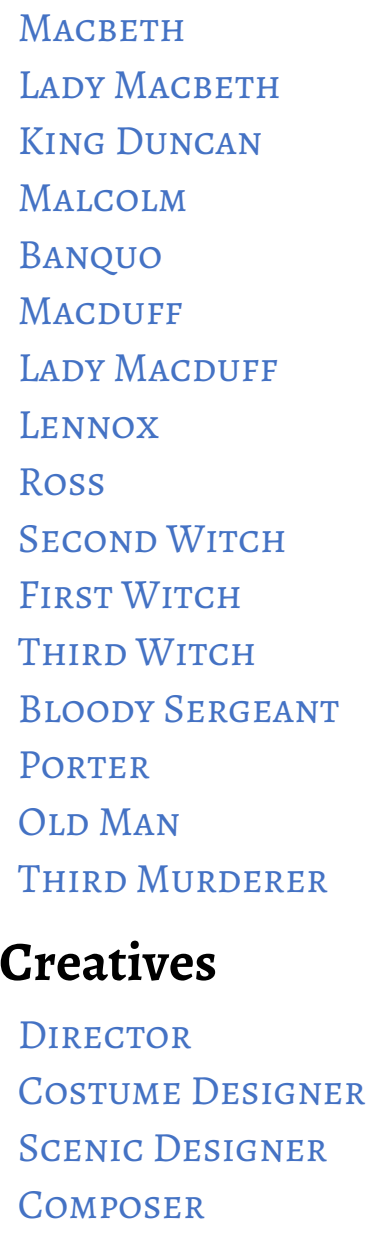

Macbeth

2015

The Public Theater

Public Theater Mobile Unit (USA)

2015-04-24

2015-06-07

\author{
ROB CAMPBELL \\ JENNIFER IKEDA \\ JENNIFER IKEDA \\ JAMES UDOM \\ DANIEL PIERCE \\ JAMES UDOM \\ KeITH ERIC ChAPPELL \\ DANiEl Pierce \\ NICOLE LEWIS \\ KeITH ERIC CHAPPELL \\ JENNIFER IKEDA \\ NiCK MILlS \\ Teresa Avia Lim \\ NiCK MILlS \\ JAMES UDOM \\ JENNIFER IKEDA
}


Production Stage Manager Nicole Lewis 